\title{
Cultures matérielles
}

Une anthologie en forme de manuel (Volume 2)

\section{Gil Bartholeyns, Nicolas Govoroff et Frédéric Joulian}

\section{(2) OpenEdition}

Journals

Édition électronique

URL : https://journals.openedition.org/tc/5010

DOI : $10.4000 /$ tc. 5010

ISSN : 1952-420X

Éditeur

Éditions de l'EHESS

Édition imprimée

Date de publication : 30 juin 2010

Pagination : 380-381

ISSN : 0248-6016

Référence électronique

Gil Bartholeyns, Nicolas Govoroff et Frédéric Joulian, «Cultures matérielles », Techniques \& Culture [En ligne], 54-55 | 2010, mis en ligne le 30 juin 2013, consulté le 29 septembre 2022. URL : http:// journals.openedition.org/tc/5010; DOI : https://doi.org/10.4000/tc.5010 

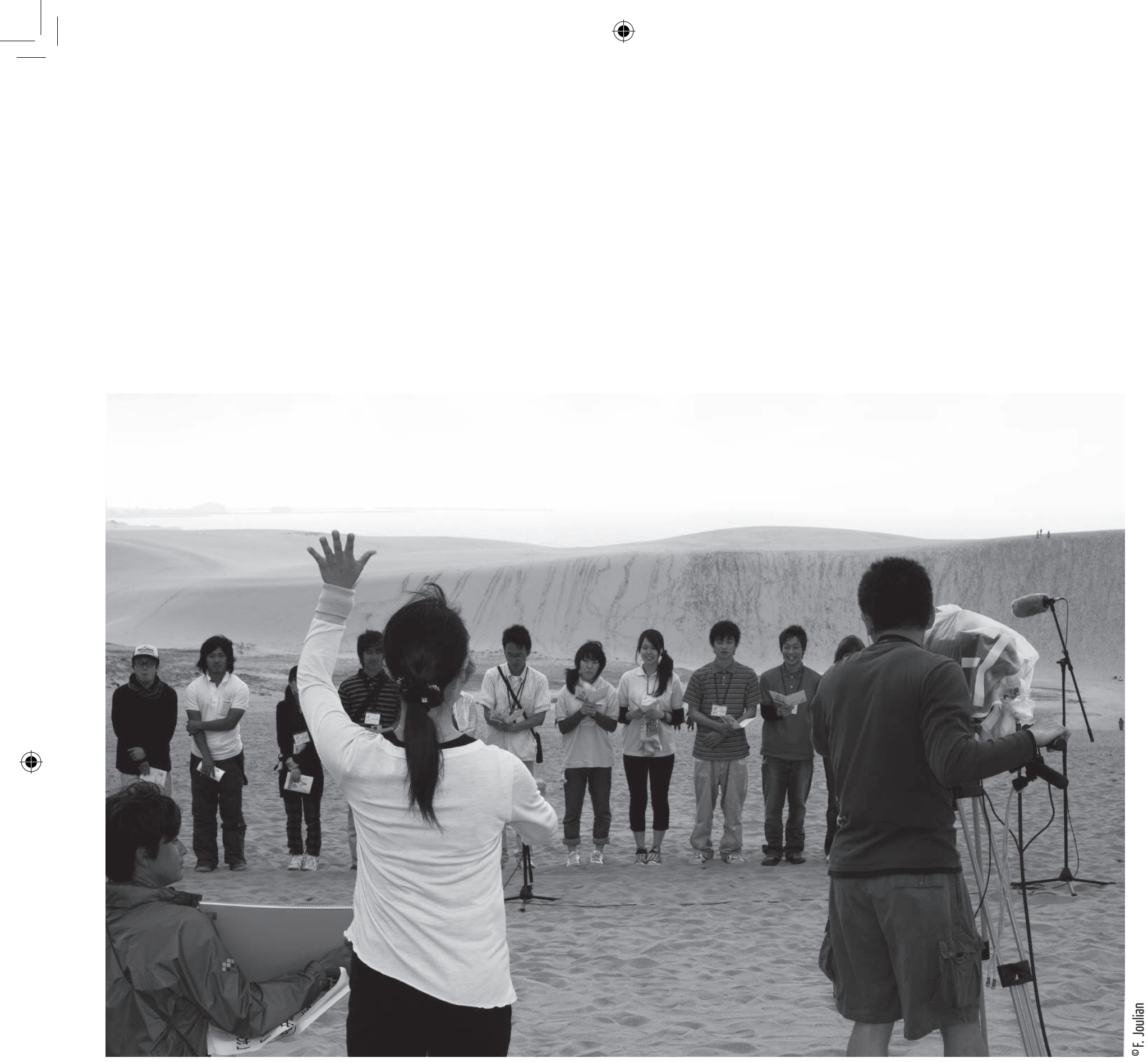

$\oplus$ 
Gil Bartholeyns, Nicolas Govoroff,

\section{Frédéric Joulian}

Université Lille 3 - CNRS, EHESS

gilbartho@gmail.com, Frederic.Joulian@ehess.fr

\section{CULTURES MATÉRIELLES}

\section{Une anthologie en forme de manuel}

Dans ce deuxième volume de l'Anthologie, le lecteur retrouvera quelques uns des principaux acteurs de la technologie culturelle et seize de leurs articles organisés en quatre parties restituant (V) les dimensions évolutives et expérimentales, (VI) les économies matérielles et symboliques des sociétés, (VII) la question du style et des techniques du corps, et finalement (VIII) les techniques contemporaines modérées au filtre du savoir des sciences de l'homme.

Pour une mise en perspective de l'ensemble de l'ouvrage nous renvoyons le lecteur à l'introduction en ouverture du volume 1 .

\section{Cultures matérielles}

Techniques \& Culture 54-55 volume 2, 2010 : 380-381 